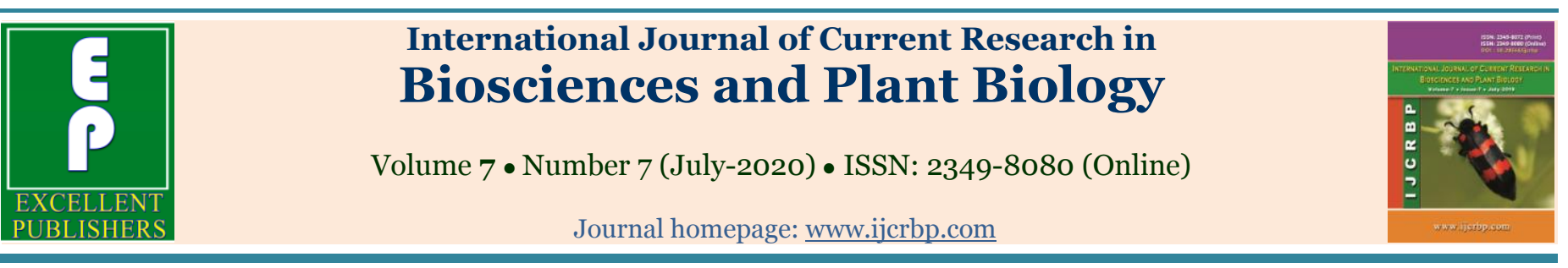

\title{
Ethnobotanical survey of medicinal plants used for the treatment of typhoid fever in Kaduna Metropolis, Nigeria
}

\author{
Sani Musa Aliyu'*, Nura Salisu², Ibrahim Ahmad Muhammad3, Sharif Umar4, \\ Alkali Fatima Zahra² and Abdulaziz Umar Kurya5
}

\begin{abstract}
${ }^{1}$ Department of Clinical Research, School of Allied Health Sciences, Sharda University, Uttar Pradesh-201 306, India ${ }^{2}$ Department of Biology, Ahmadu Bello University, Zaria, Nigeria

3Department of Biochemistry, Kano University of Science and Technology, Wudil, Kano, Nigeria 4Department of Biology, Yusuf Maitama Sule University, Kano, Nigeria

${ }^{5}$ School of Life and Allied Health Sciences, Glocal University, Saharanpur, Uttar Pradesh-247 001, India
\end{abstract}

${ }^{*}$ Corresponding author; e-mail: 2019008695.sani@pg.sharda.ac.in

\begin{tabular}{|c|c|}
\hline Article Info & \multirow{4}{*}{$\begin{array}{l}\text { Typhoid fever had become one of the most serious infectious diseases among the urban } \\
\text { populace of Kaduna metropolis, Northern Nigeria due to its escalating cost of treatment } \\
\text { via the conventional system, current economic melt-down, and drug-resistant strategy } \\
\text { of the Salmonella spp. People, therefore, resorted back to the use of medicinal drugs } \\
\text { that are cost-effective with no side effects. An ethnobotanical survey was conducted to } \\
\text { identify the medicinal plants used for the treatment of typhoid fever in Kaduna } \\
\text { metropolis to establish a check-list of the pharmacognostic activity of the most } \\
\text { frequently used plant. Self-structured questionnaires were administered among } \\
\text { herbalists and individuals representing the consumer population. Plant specimen were } \\
\text { also collected along the line, identified and authenticated at the herbarium of the } \\
\text { Department of Botany, Ahmadu Bello University, Zaria, Nigeria. The results obtained } \\
\text { revealed that } 40 \text { different plant species representing } 29 \text { families of plants were used in } \\
\text { the treatment of typhoid fever in Kaduna. Among the most frequently used species } \\
\text { include Alchornea cordifolia, Balanites aegyptiaca, Blighias apida, Datarium } \\
\text { microcarpum, Gardenia aqualla, Grewia mollis, Lawsonia inermis, Morinda lucida, } \\
\text { Nanclei latifolia, Ocimum gratissimum, Plumeria rubra, and Mangifera indica. It was } \\
\text { found that the leaves and stem were the major parts used for herbal preparation and } \\
\text { were administered orally in the form of decoction and infusion. Furthermore, need for } \\
\text { incorporating the traditional herbalists in the management of typhoid fever by } \\
\text { orienting them through seminars and workshops on how to formulate standard doses } \\
\text { for the treatment strategies. Thus, medicinal herbs are effective in the treatment of } \\
\text { typhoid fever. }\end{array}$} \\
\hline $\begin{array}{l}\text { Date of Publication: } \\
\text { o6 July } 2020\end{array}$ & \\
\hline Keywords & \\
\hline $\begin{array}{l}\text { Decoction } \\
\text { Herbalists } \\
\text { Infusion } \\
\text { Medicinal plan } \\
\text { Typhoid fever }\end{array}$ & \\
\hline
\end{tabular}




\section{Introduction}

Typhoid fever is an acute illness associated with fever that is most often caused by the bacteria Salmonella typhi transmitted through the ingestion of food or drink that is contaminated by the feces or urine of infected persons (Obanu et al., 2019). Each year the disease affects at least 16 million people worldwide, most of whom reside in the developing countries of Southeast Asia and Africa (Keddy et al., 2018). Typhoid fever caused by Salmonella typhi has since 1989 developed simultaneous resistance to conventional antibiotics of choice in several endemic areas (Dahiya et al., 2019). The burden of typhoid fever remains high in impoverished settings, and increasing antibiotic resistance is making treatment costly. The problem has become endemic in many developing countries, causing enormous morbidity and high cost of treatment. This has resulted in a pressing need to search for alternative and newer antimicrobials with a novel mode of action against typhoid fever particularly from plants and their derivatives (Crump, 2019).

Medicinal plants have been used for the treatment of several human diseases over the century and have been very important in the health care delivery of every nation at one stage or the other (Umair et al., 2019). Recent research has focused on natural plant products as alternatives to the existing drugs for disease remedy in developing countries (Liu and Quinn, 2019). Plant-derived medicines have been part of traditional health care in most parts of the world for ages and there is increasing interest in them as sources of agents to fight microbial diseases (Bouarab Chibane et al., 2019). Herbal medicine is readily available in our diverse vegetation, cheap and above all carries the potential for introducing new templates into modern medicine (Zhang et al., 2018). In Nigeria, herbal medicine practitioners are still consulted as a first choice in the treatment of ailments, since traditional medicine blends readily with the sociocultural life of the people, and the fact that orthodox medicine is more expensive to procure and some orthodox pharmaceutical preparations are many times faked. In Nigeria therefore, traditional medicine is well acknowledged and established as a viable profession due to their perception that almost all plants seem to have some kind of application in traditional medicine
(Salim, Muhammad Asad et al., 2019). This study therefore aimed at surveying medicinal plants used in the treatment of typhoid fever in Kaduna metropolis.

\section{Materials and methods}

\section{Study area}

The study was conducted within Kaduna metropolis, Northwestern Nigeria. Before the study, signed consent forms from each interviewee were obtained. These individuals constituted traditional herbalists and patients as well as other traders (herbalists).

\section{Inclusion criteria}

Well known and established traditional herb sellers, traditional medical practitioners, and herbalists who are healthy and mentally stable, practicing their jobs at the time of the study were selected.

\section{Exclusion criteria}

Unrecognized traditional herb sellers, traditional medical practitioners, and herbalists with poor patronage, mentally ill, and not practicing their jobs at the time of the study were excluded.

\section{Ethical approval}

The objectives of the study were explained to the respondents (traditional herb sellers, traditional medical practitioners, and herbalists) and informed consent was obtained from each respondent.

\section{Research design}

The project was a cross-sectional descriptive study. An ethnobotanical survey was conducted from June to October 2019 to obtain relevant information about the use of medicinal plants in the treatment of Typhoid fever in Kaduna metropolis, Nigeria. A total of 100 subjects were sampled to represent the population of traditional herbalists and the consumer population. Due to the low education level or lack of understanding of the English language of most of the subjects, the structured questionnaires were discussed on an 
individual basis and explained by the researchers using their interviewee's native language (Hausa language) which is also the first language of most of the researchers. The results were then transcribed by the researchers as many could not write. Data were collected based on an oral interview with the aid of a pre-tested, validated, and reliable self-structured questionnaire. Only data from willing respondents were obtained and documented. Plant specimens were collected along the line; subsequently, dried and mounted according to the method described by Sofowora (1996). Many of the traditional healers/herbalists provided the local names of the plants being used. It was then taken for identification and authentication in the Herbarium Section of the Department of Botany, Ahmadu Bello University, Zaria for assigning specimen voucher numbers.

\section{Data analysis}

Data obtained were analyzed in frequency distribution tables and percentages.

\section{Results}

The demographic survey of respondents is presented in Table 1 shows that from the one hundred respondents interviewed within Kaduna metropolis, $74 \%$ were herbalists, followed by farmers with $26 \%$. The distribution indicated that the majority of the respondents were males (80\%) while $20 \%$ of them were females. The result also indicated that the highest numbers of subjects were between the age range of 61 and 70 years (40\%) while the least number were between the age range of 20 and 30 years with (2\%).

The result for the list of plants used in the treatment of typhoid fever in Kaduna metropolis as presented in Table 2 shows that a total of 40 plant species represented by 24 families were used within Kaduna metropolis by the different categories of practitioners in the treatment of typhoid fever.

However, Table 3 shows the recipes, methods of preparation, and administration of the medicinal herbs used in the treatment of typhoid fever in Kaduna metropolis. The result showed that most of the herbs were administered orally in the form of decoction.
Table 1. Demographic characteristics of respondents.

\begin{tabular}{lll}
\hline Variables & Frequency & Percentage (\%) \\
\hline Occupational status & \\
Herbalists & 74 & 74 \\
Farmers & 26 & 26 \\
Total & 100 & 100 \\
Sex & & \\
Male & 80 & 80 \\
Female & 20 & 20 \\
Total & 100 & 100 \\
Age & & \\
$20-30$ & & 2 \\
$31-40$ & 2 & 4 \\
$41-50$ & 4 & 10 \\
$51-60$ & 10 & 20 \\
$61-70$ & 20 & 40 \\
$>70$ & 40 & 24 \\
Total & 24 & 100 \\
\hline
\end{tabular}

\section{Discussion}

Medicinal plants used to treat typhoid fever are of considerable interest for the ethnobotanical community as they are recognized to contain valuable medicinal properties in different parts of the plant and quite a several plants have shown varying degrees of hypoglycemic and antihyperglycemic activity. The use of medicinal plants among elderly people obtained in this study was in line with their deep knowledge of sourcing and preparing different traditional medicines from those plants (Kim et al., 2019). A research article shows that plant leaves and stem barks are the most important ingredient in traditional treatment of typhoid fever which is consistent to methods of formulation of drugs using different parts of the plant as discussed in Table 2 (Alam et al., 2018 and 2019).

The active principles of many plant species with desired properties are isolated to cure aliments; this was confirmed by a survey of 40 medicinal plant species conducted which belonging to 29 families use in the management of typhoid fever in Kaduna metropolis (Zhu et al., 2018; Kidane et al., 2018). Interestingly, Most of the plants identified in this research are consistent with those previously identified elsewhere for the management of typhoid fever. 
Table 2. Medicinal plants used for the treatment of typhoid fever within Kaduna metropolis.

\begin{tabular}{|c|c|c|c|c|}
\hline $\mathbf{S} / \mathbf{N}$ & Botanical names & Family & Local names & Plant part used \\
\hline 1 & Albizia ferruginea & Mimosaceae & & Whole plant \\
\hline 2 & Allium sativum & Liliaceae & Tafarnuwa & Bulb \\
\hline 3 & Alchornea cordifolia & Euphorbiaceae & Bambami & Leaves \\
\hline 4 & Ananas comosus & Bromeliaceae & Abarba & Unripe fruit \\
\hline 5 & Citrus paradisiac & Rutaceae & Furuntu & Fruits \\
\hline 6 & Balanites aegyptiaca & Balanitaceae & Aduwa & Leaves \\
\hline 7 & Blighia sapida & Sapindaceae & Gwanjakusa & Leaves \\
\hline 8 & Cassia tora & Caesalpinaceae & & Leaves \\
\hline 9 & Cymbopogon citratus & Poaceae & Isauri & Leaves \\
\hline 10 & Carica papaya & Caricaceae & Gwanda & Leaves \\
\hline 11 & Cymbopogon giganteus & Poaceae & & \\
\hline 12 & Cocos nucifera & Palmae & Kwakwa & Fruits \\
\hline 13 & Daniella oliveri & Caesalpiniaceae & Maje & Leaves and bark \\
\hline 14 & Datarum microcarpum & Caesalpiniaceae & Taura & Leaves \\
\hline 15 & Enantia chlorantha & Amonaceae & & Stem bark \\
\hline 16 & Eriosema psoraleoides & Fabaceae & Tabajiki & Leaves \\
\hline 17 & Ficus platyphylla & Moraceae & Gamji & Leaves \\
\hline 18 & Gardenia aqualla & Rubiaceae & Gaude & Roots and leaves \\
\hline 19 & Grewia mollis & Tiliaceae & Dargaji & Stem bark \\
\hline 20 & Khaya senegalensis & Mimosaceae & Madaci & Leaves and Bark \\
\hline 21 & Lawsonia inermis & Lythraceae & Lalle & Leaves \\
\hline 22 & Magnifera indica & Anarcardiaceae & Mangwaro & Matured bark and leaves \\
\hline 23 & Moringa oleifera & Moringaceae & Zogale & Leaves \\
\hline 24 & Morinda lucida & Rubiaceae & & Stem bark and leaves \\
\hline 24 & Nauclea latifolia & Rubiaceae & Tafashiya & Stem bark and leaves \\
\hline 25 & Olax subscorpiodea & Olaceae & Gwanonkurmi & Root \\
\hline 26 & Ocimum grastissimum & Lamiaceae & Daidoya ta gida & Leaves \\
\hline 27 & Plumeria rubra & Apocynaceae & Karya & Leaves \\
\hline 28 & Psidium guajava & Myrtaceae & Gwaiba & Stem bark and leaves \\
\hline 29 & Saccharum officinarum $L$. & Poaceae & Rake & Matured stem \\
\hline 30 & Sorghum bicolor & Poaceae & Dawa & Leaves \\
\hline 31 & Spondias mombin & Anacardiaceae & Tsadarmasar & Stem bark and leaves \\
\hline 32 & Securidaca longipedunculata & Polygalaceae & Uwarmagunguna & Leaves, stem bark and roots \\
\hline 33 & Senna occidentalis & Caesalpiniaceae & Raidaure & Leaves \\
\hline 34 & Terminalia avicenniodes & Combretaceae & Baushe & Leaves \\
\hline 35 & Azadirachta indica & Meliaceae & Dogonyaro & Stem bark and leaves \\
\hline 36 & Vernonia amygdalina & Asteraceae & Shuwaka & Leaves \\
\hline 37 & Vitex doniana & Verbenaceae & Dinya & Bark and Root \\
\hline 38 & Ximenia Americana & Olacaceae & Tsada & Stem bark and leaves \\
\hline 39 & Zingiberofficinale & Zingiberaceae & Chitta & Rhizome \\
\hline 40 & Ziziphus abyssinica & Rhamnaceae & Magariyakura & Root and stem bark \\
\hline
\end{tabular}


Table 3. Enumeration of the recipes, methods of preparations and administration.

\begin{tabular}{|c|c|}
\hline $\mathbf{S} / \mathbf{N}$ & Recipe \\
\hline 1 & $\begin{array}{l}\text { Ananas comosus, Cymbopogon citratus, Citrus medica, Citrus sinensis, Mangifer aindica and Vitex } \\
\text { doniana: These herbs are boiled in water or aqueous extract from fermented maize. Take a full cup } 3 \text { times } \\
\text { daily. }\end{array}$ \\
\hline 2 & Citrus medica and Ananas comosus: Freshly extracted juices from their fruits should be taken orally. \\
\hline 3 & $\begin{array}{l}\text { Carica papaya and Allium sativum: The ingredients are cut into pieces and boiled in water for an hour. A } \\
\text { full tumbler should be taken twice daily }\end{array}$ \\
\hline 4 & $\begin{array}{l}\text { Olax subscorpioidea, Vitex doniana, Zingiber officinale, Allium sativum, and Ananas comosus: Boiling in } \\
\text { water for } 2 \text { hours. Half tumbler of the concoction should be taken morning and night for } 7 \text { days }\end{array}$ \\
\hline 5 & $\begin{array}{l}\text { Carica papaya and Zingiber officinale: Unripe fruits of Carica papaya and ground portion of the } \\
\text { Zingiber officinale (rhizome) should be soaked in a small quantity of water for } 24 \text { hours. A full tumbler of } \\
\text { the extract was taken twice daily for } 7 \text { days. }\end{array}$ \\
\hline 6 & $\begin{array}{l}\text { Khaya senegalensis: This herb is boiled in water and half tumbler of concoction taken twice daily for } 5 \\
\text { days. }\end{array}$ \\
\hline 7 & Vitex doniana and Khaya senegalensis: Boil in water for 30 mins and drink twice daily for 10 days. \\
\hline 8 & $\begin{array}{l}\text { Vernonia amygdalina and Citrus medica: Squeezing of the Vernonia leaf in water and mixing extracts } \\
\text { with juices of the Citrus fruits. Half tumbler taken } 3 \text { times daily for } 7 \text { days. }\end{array}$ \\
\hline 9 & $\begin{array}{l}\text { Moringa oleifera, Allium sativum and Ananas comosus: Boil the herbs in water or aqueous extract from } \\
\text { fermented maize. Half tumbler taken twice daily for } 14 \text { days }\end{array}$ \\
\hline 10 & $\begin{array}{l}\text { Carica papaya and Mangifera indica: Boiled with aqueous extract from fermented maize. Half tumbler } \\
\text { took twice daily. }\end{array}$ \\
\hline 11 & $\begin{array}{l}\text { Olax subscorpioidea and Albizia ferruginea: The barks of these herbs soaked in water for } 2 \text { days and a half } \\
\text { tumbler of the concoction taken once daily for } 10 \text { days }\end{array}$ \\
\hline 12 & $\begin{array}{l}\text { Albizia ferruginea, Daniellia oliveri and Anana scomosus: Boil herbs using water or aqueous extract from } \\
\text { fermented maize for } 2 \text { hours. Concoction taken } 3 \text { times daily for } 7 \text { days. }\end{array}$ \\
\hline 13 & $\begin{array}{l}\text { Saccharum officinarum and Albizia ferruginea: Boil the herbs in water for an hour. Half tumbler taken } \\
\text { twice daily for } 14 \text { days. }\end{array}$ \\
\hline 14 & $\begin{array}{l}\text { Albizia ferruginea and Cymbopogon giganteus: Boil the herbs in water for an hour. Half tumbler taken } \\
\text { twice daily for } 10 \text { days. }\end{array}$ \\
\hline 15 & $\begin{array}{l}\text { Senna obtusifolia: Soak the ingredient in water for } 3 \text { days or boiling in water for } 6 \text { hours. Then drinking } \\
\text { half tumbler twice daily. }\end{array}$ \\
\hline 16 & $\begin{array}{l}\text { Daniellia oliveri: Boiling of this herb in an earth pot with water for } 15 \text { hours and bath with the extracts } \\
\text { after cooling daily for } 3 \text { days. }\end{array}$ \\
\hline 17 & Mangifera indica: Grind the dried bark of mango tree, sieve, and macerate with water .1 cup twice a day. \\
\hline 18 & Pulmeria rubra: Fresh leaves are boiled together with red potash. One cupful twice a day. \\
\hline 19 & $\begin{array}{l}\text { Khaya senegalensis and Daniella oliveri: The stem barks are broken into pieces and macerated with cold } \\
\text { water overnight. A cup twice daily }\end{array}$ \\
\hline 20 & Ananas comosus: The fruits are boiled together with lemongrass. Half cup to be taken thrice a day \\
\hline 21 & Lawsonia inermis: Dried leaves are pounded smoothly and a tablespoon is taken with pap thrice a day. \\
\hline 22 & $\begin{array}{l}\text { Ocimum gratissimum: Fresh leaves are pounded and infused in cold water. One cupful twice a day. An } \\
\text { aqueous decoction of whole plant. Half cup to be taken thrice a day }\end{array}$ \\
\hline 23 & $\begin{array}{l}\text { Carica papaya and Psidium guajava: The leaves are boiled together and taken twice a day. The patient } \\
\text { also baths with it. }\end{array}$ \\
\hline 24 & Morinda lucida: Aqueous decoction of the leaves. Half cup to be taken thrice a day \\
\hline
\end{tabular}


Several research articles have proved the effectiveness of some medicinal plants in the management of typhoid fever, the plants include: Albizia ferruginea, Ananas comosus, Citrus medica, Mangifera indica, Olax subscorpioidea, Vitex doniana, Zingiber officinale, Allium sativum, Khaya senegalensis, Vernonia amygdalina, Ficus platyphylla, Moringa olifera, Citrus paradisica, Carica papaya, Xylopia aethiopica, Saccharum officinarum, Daniellia oliveri, Cymbopogon giganteus, Cassia tora, Alchornea cordifolia, Balanites aegyptiaca, Blighia sapida, Datarium microcarpum, Gardenia aqualla, Grewia mollis, Lawsonia inermis, Morinda lucida, Nanclei latifolia, Ocimum gratissimum, Pulmeria rubra, Psidium guajava, Sorghum bicolor, Spondias mombin, Cymbopogon citratus, Securidaca longipenculata, Eriosema psoraleides, Vernonia amygdalina, Ximena Americana and Ziziphus abyssinica.

\section{Conclusion}

The increased use of medicinal plants around the globe as shown In this article that Twenty-nine (29) families representing 40 species of indigenous plants were used in the treatment of typhoid fever in Kaduna metropolis draws a lot of attention and declare the need of scientist and researchers to critically analyze and isolate the active components in these medicinal plants for the development of effective and affordable drugs that will help in curing several diseases including typhoid fever.

\section{Conflict of interest statement}

Authors declare that they have no conflict of interest.

\section{Acknowledgement}

We acknowledge the effort from Department of Clinical Research, School of Allied Health sciences, Sharda University, Department of Biology, Ahmadu Bello Universityzaria, Department of Biochemistry, Kano University of Science and Technology, Wudil, Kano, Department of Biology, Yusuf Maitama Sule University, Kano, and School of life and allied health sciences, Glocal University, Saharanpur, for their foremost contribution towards completion of the research work and ultimately to commend the effort of traditional herb sellers, medical practitioners who share their experience about those herbal plants and their uses traditionally that helps in compiling the data used in this research.

\section{References}

Alam, F., Shah, A. J., 2019. Butyrlycholine esterase inhibitory activity and effects of extracts (fruit, bark and leaf) from Zanthoxylum armatum DC in gut, airways and vascular smooth muscles. BMC Compl. Alt. Med. 19(1), 180.

Alam, F., Saqib, Q., Ashraf, M., 2018. Zanthoxylum armatum DC extracts from fruit, bark and leaf induce hypolipidemic and hypoglycemic effects in mice- in vivo and in vitro study. BMC Compl. Alt. Med. 18(1), 68.

Bouarab Chibane, L., Degraeve, P., Ferhout, H., Bouajila, J., Oulahal, N., 2019. Plant antimicrobial polyphenols as potential natural food preservatives. J. Sci. Food Agric. 99(4), 1457-1474.

Crump, J. A., 2019. Progress in Typhoid Fever Epidemiology. Clin. Infect. Dis. 68 (Suppl 1): S4- S9.

Dahiya, S., Malik, R., Sharma, P., Sashi, A., Lodha, R., Kabra, S. K., Sood, S., Das, B. K., Walia, K., Ohri, V. C., Kapil, A., 2019. Current antibiotic use in the treatment of enteric fever in children. Indian J. Med. Res. 149(2), 263-269.

Keddy, K.H., Smith, A.M., Sooka, A., Tau, N.P., Ngomane, H.M., Radhakrishnan, A., Als, D., Benson, F.G., 2018. The burden of typhoid fever in South Africa: the potential impact of selected interventions. Am. J. Trop. Med. Hyg. 99(3 Suppl.), 55- 63.

Kidane, L., Gebremedhin, G., Beyene, T., 2018. Ethnobotanical study of medicinal plants in Ganta Afeshum District, Eastern Zone of Tigray, Northern Ethiopia. J. Ethnobiol. Ethnomed. 14(1), 64.

Kim, J.H., Im, J., Parajulee, P., Holm, M., Cruz Espinoza, L.M., Poudyal, N., Mogeni, O.D., Marks, F., 2019. A systematic review of typhoid fever occurrence in Africa. Clin. Infect. Dis. 69(Suppl 6): S492- S498.

Liu, M., Quinn, R. J., 2019. Fragment-based screening with natural products for novel antiparasitic disease drug discovery. Expert Opin. Drug Discov. 14(12), 1283- 1295.

Ohanu, M. E., Iroezindu, M. O., Maduakor, U., Onodugo, O. D., Gugnani, H. C., 2019. Typhoid fever among febrile Nigerian patients: 
Prevalence, diagnostic performance of the Widal test and antibiotic multi-drug resistance. Malawi Med. J. 31(3), 184- 192.

Salim, M.A., Ranjitkar, S., Hart, R., Khan, T., Ali, S., Kiran, C., Parveen, A., Batool, Z., Bano, S., $\mathrm{Xu}$, J., 2019. Regional trade of medicinal plants has facilitated the retention of traditional knowledge: case study in Gilgit-Baltistan Pakistan. J. Ethnobiol. Ethnomed. 15(1), 6.

Umair, M., Altaf, M., Bussmann, R. W., Abbasi, A. M., 2019. Ethnomedicinal uses of the local flora in Chenab riverine area, Punjab province, Pakistan. J. Ethnobiol. Ethnomed. 15(1), 7.

Zhang, L., Dou, X. W., Zhang, C., Logrieco, A. F., Yang, M. H., 2018. A review of current methods for analysis of mycotoxins in herbal medicines. Toxins (Basel). 10(2), 65.

Zhu, B., Zhang, Q. L., Hua, J. W., Cheng, W. L., Qin, L. P., 2018. The traditional uses, phytochemistry, and pharmacology of Atractylodes macrocephala Koidz.: A review. J. Ethnopharmacol. 226, 143-167.

\section{How to cite this article:}

Aliyu, S. M., Salisu, N., Muhammad, I. A., Umar, S., Zahra, A. F., Kurya, A. U., 2020. Ethnobotanical survey of medicinal plants used for the treatment of typhoid fever in Kaduna Metropolis, Nigeria. Int. J. Curr. Res. Biosci. Plant Biol. 7(7), 47-53. doi: https://doi.org/10.20546/ijcrbp.2020.707.005 